\title{
Calcareous Nannofossils in Surface Sediments of the Central and Northern Parts of the South China Sea
}

\author{
CHENG XINRONG \\ Department of Marine Geology, Tongii University, \\ Shanghai 200092, P. R. China
}

\begin{abstract}
Taxonomic composition and quantitative distribution of calcareous nannofossils in the nothern and central parts of the South China Sea were studied in 146 samples of surface sediments taken from estuary, continental shelf, continental slope and deep-water basin. This paper reports distribution patterns of nannofossils in the area, including nannofossil abundance, species, assemblages and specimen size. Abundance increases from shelf to slope, with a decrease from the lower part of the slope towards the abyssal plain. The assemblages are dominated by Emiliania huxleyi, Gephyrocapsa oceanica and Florisphaera profunda. Ecologically the effects of water temperature, and nutrient inputs can be detected in the distribution of nannofossils, while dilution by terrigenous materials and deep sea carbonate dissolution influence the sedimentological aspect of the samples. The composition of the South China Sea nannofossil assemblage enables it to be grouped with the central zone of the North Pacific in biogeographic zonations of nannoplankton. J. Micropalaeontol., 11 (2): 167-176, December 1992.
\end{abstract}

\section{INTRODUCTION}

In the Chinese sea area, systematic research on calcareous nannofossils from surface sediments has been concentrated in the East China Sea (Wang and Min, 1981; Wang and Samtleben, 1983; Wang and Cheng, 1985; Zhang and Siesser, 1986). In the South China Sea, Okada and Honjo (1975) analysed calcareous nannoplankton in 61 water samples collected south of $11^{\circ} \mathrm{N}$, also Chen and Shieh (1982), Okada (1983) analysed calcareous nannofossils in surface sediment samples from the southern part of the Sea. Okada (1983) studied samples from the Gulf of Thailand, Chen and Shieh (1982) mainly worked on the Sunda Shelf and Southern Basin of the Sea. Varol (1985) studied calcareous nannofossils from nearshore localities in Jason Bay. There have been no previous studies of the calcareous nannofossils in the surface sediments of the northern part of the South China, which are the subject of this study.

\section{STUDY AREA}

The samples were collected from the the northern part of the South China Sea $\left(12^{\circ}-23^{\circ} \mathrm{N}, 108^{\circ}-118^{\circ} \mathrm{E}\right)$ (Fig.1), including the eastern part of Beibu Gulf, continental shelf, continental slope, and abyssal plain. Two major rivers flow into the area - the Zhujiang (Pearl) River and the Hanjiang River. The bottom topography of the area is high in the northwest and low in the southeast, the maximum water depth in the area is over $4000 \mathrm{~m}$. The shelf / slope boundary is at a depth of approximately $150 \mathrm{~m}$. The abyssal plain starts at approximately 3600m (Physical Geography of China Compilation Committee, 1979). From continental shelf to abyssal plain, the clastic sediments fine gradually, the $30 \%$ sand contour is at about $200 \mathrm{~m}$ (Fig.2a); and $\mathrm{CaCO}_{3}$ content gradually declines, it is less than $10 \%$ below a water depth of $3500 \mathrm{~m}$ (Fig.2b).

\section{MATERIALS AND METHODS}

146 samples were studied; 100 of these were collected during 1983-84 by the Second Institute of Oceanography, StateOceanic Administration, 46 were collected during $1974-78$ by South China Sea Headquarters of Geological Survey, MGMR (Fig.1).

Light microscope slides were prepared by diluting 0.1 grams of sediment in 40 millilitres of distilled water and spreading a drop of the slurry on a cover glass $\left(24 \times 32 \mathrm{~mm}^{2}\right)$. All samples were studied under polarised light microscope (Leitz ORTHOLUX 2 POL BK). The number of nannofossils per 10 randomly selected fields of view at $\mathrm{X} 630$ magnification was used as the nannofossil abundance of the sample. If this abundance was under 300 , a further 10 fields were examined, and the results averaged. In addition, these abundances are converted to specimens per gram of sediment (Tab.1) (specimens per gram of sediment $=$ specimens per 10 fields of view $X\left(24 \times 32 \mathrm{~mm}^{2} / 10\right.$ fields of view area $) \times(40 \mathrm{ml} /$ drop volume $) X(1 \mathrm{~g} / 0.1 \mathrm{~g})=$ specimens per 10 fields of view $X 1300$ $X 880 \times 10=$ specimens per 10 fields of view $X 11.44$ million). If the difference between specimens per 10 fields of view counted in different times is 1 , the difference between specimens per gram of sediment estimated in different times will be 11.44 million. The estimate of specimens per gram of sediment is accurate to at most $10^{7}$. Seventy-one samples with more abundant nannofossils were examined with a scanning electron microscope (Hitachi H-8010 SEM part of Hitachi $\mathrm{H}$ 800 transmission electron microscope) at $X 5000$ magnification. In forty-eight of them, with the most abundant nannofossils, the assemblages were counted (counts of more than 300 specimens) to assess the relative abundance of taxa and specimen size. 


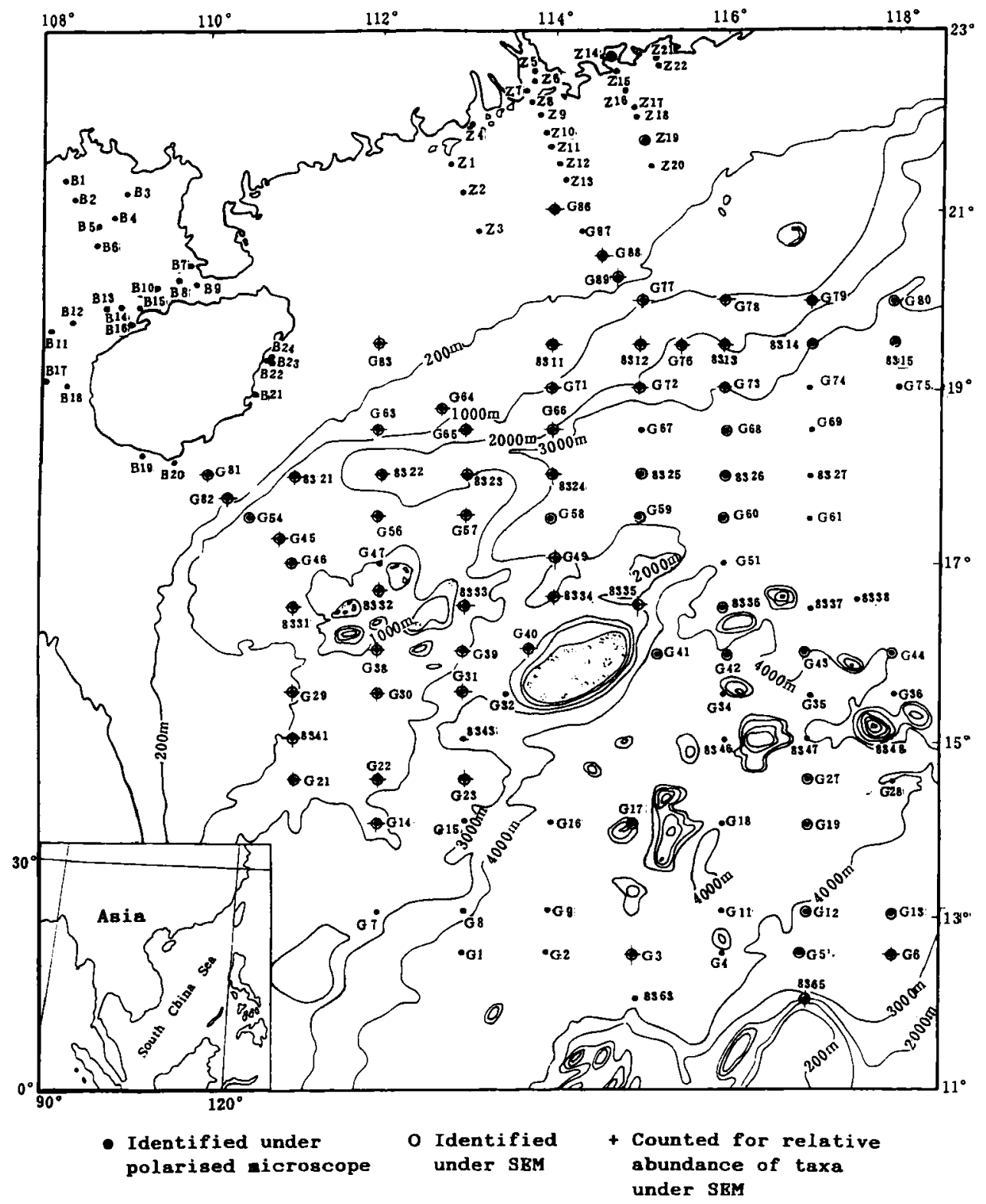

Fig. 1. Localities of sample stations: identified under polarised microscope, $O$ identified under electron microscope, counted for relative abundance of taxa under electron microscope (Topographic map reduced from South China Sea Institute of Oceanology, Academia Sinica, 1981).

\section{RESULTS}

Nannofossil Abundance

The abundance distribution of calcareous nannofossils (Fig.2c) is closely related to water depth. Specimens are widely distributed in the samples, from nearshore at a water depth of few metres to the deep basin at a water depth of more than 4000 metres. However, the abundances range from 0 to 1664 . Abundances over 300 are limited mainly to water depths of $200 \mathrm{~m}$ to $3500 \mathrm{~m}$ (Tabs.1 and 2, Fig.2c). Calcareous nannofossils form less of the sediments in the shelf area $(<200 \mathrm{~m})$ and much less of the sediments in the abyssal plain $(>3500 \mathrm{~m})$, where almost no nannofossils could be found in most samples.
Sediment grain size and carbonate content are closely related to nannofossil abundance. Nannofossil content is low in coarse sediments and high in fine sediments. For example, at stations on the northern shelf, sediments are coarse and the sand content is high, and most nannofossil abundances are less than 300 (Figs. 2a and 2c). Generally speaking, high nannofossil contents correlates with high carbonate content (Figs. $2 b$ and $2 c$ ).

\section{Species Distribution}

Twenty-nine calcareous nannofossil species or groups of species, and two species of calcareous dinoflagellates 


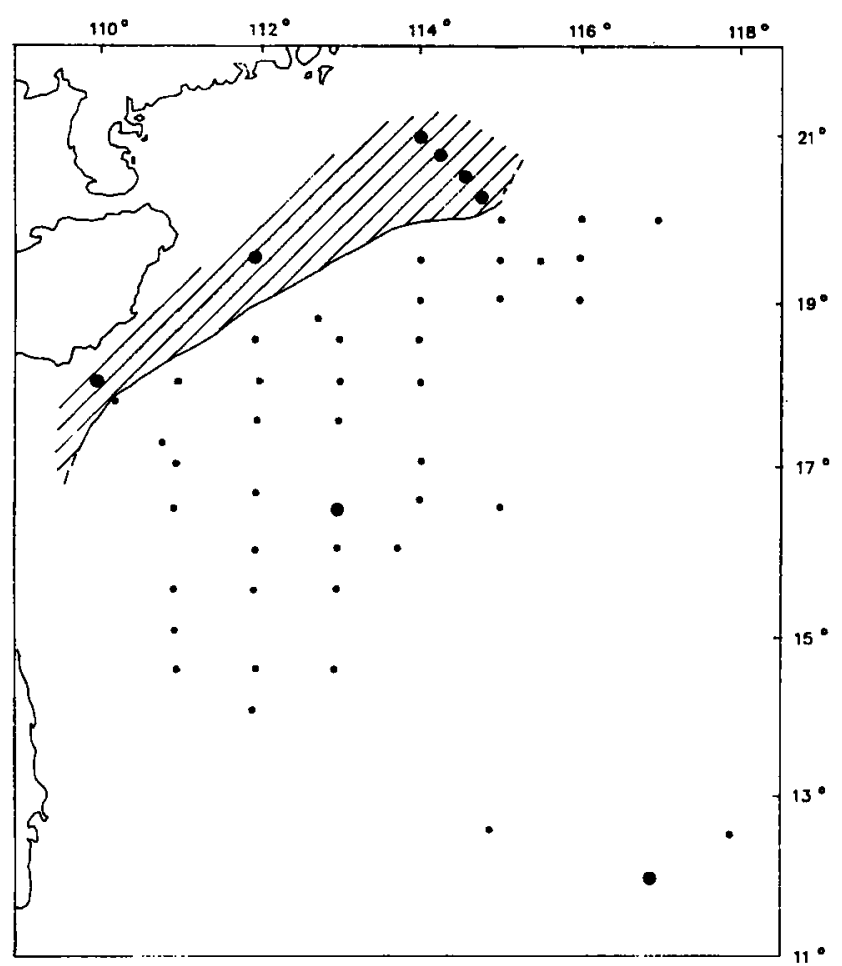

$[2 \bullet \geqslant 30 \%$

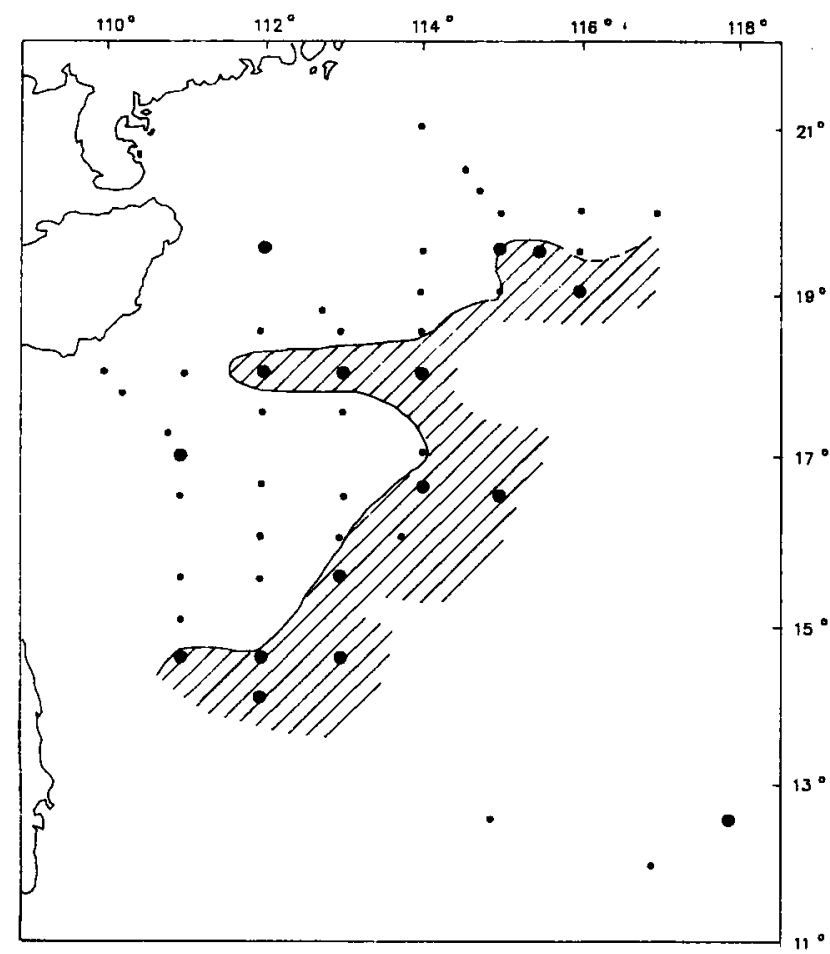

$7 \bullet \geqslant 0.7$ $\square \cdot<30 \%$

a

$\square \cdot<0.7$

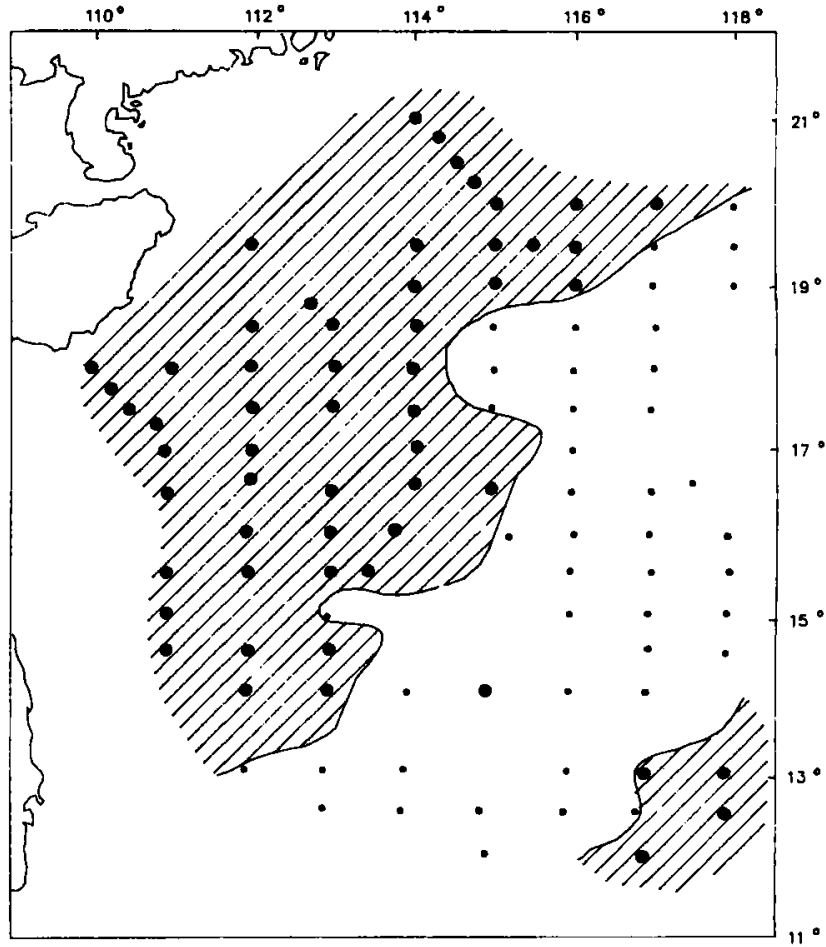

$E D \geqslant 10 \%$

$b$

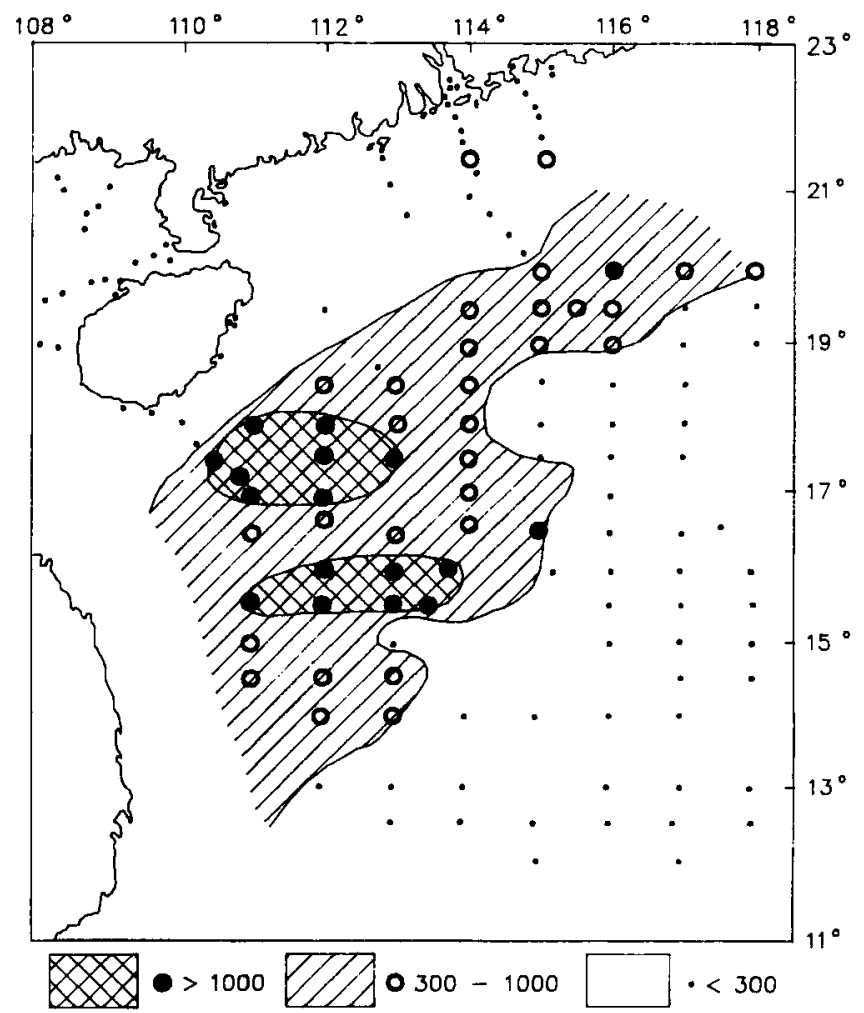

Fig. 2. (a) Sand distribution in the central and northern parts of the South China Sea; (b) $\mathrm{CaCo}_{3}$ distribution in the central and northern parts of the South China Sea; (c) Distribution of calcareous nannofossil abundance; (d) Relative abundance of broken specimens to all specimens of Emiliania huxleyi. 
(Thoracosphaera heimii and T. tuberosa), were identified (Tab.3). For each species, the percentage of samples it occurred in "frequency", and the average percentage of the total counted assemblages in "average relative abundance", are given in Table 3. In addition, some reworked nannofossils, such as Discoaster deflandrei, D. brouweri, Pseudoemiliania lacunosa, Gephyrocapsa protohuxleyi, G. aperta and Sphenolithus abies, occurred sporadically in samples from the slope (Tab.5). Distributional aspects are described below for major species.

Emiliania huxleyi (Lohmann) Hay \& Mohler. E. huxleyi(Fig.3a) is widely distributed and an abundant species in the area, it occurred in all 48 samples counted. The relative abundance per sample varies from $15.83 \%$ to $86.13 \%$, it is highest between about $150 \mathrm{~m}$ and $2000 \mathrm{~m}$ depth $(>55 \%)$. This species has the greatest biogeographic range in modern oceans (McIntyre and Bé, 1967), and is often found in nearshore seas, for example, in marginal seas of the western Pacific (Okada and Honjo, 1975; Chen and Shieh, 1982; Wang and Cheng, 1985). McIntyre and Bé (1967) described a "warm water form" and a "cold water form". The "warm water form" has T-shaped elements in both shields and a delicate plate of interconnected rods forming a grill covers the proximal side of the central opening. The "cold water form" has T-shaped elements only in the distal shield and the solid proximal shield has a central plate of thin interlocked elements completely closing the pore. These forms were identified and counted separately in the study, but there was no indication that their occurrence varied with temperature. The relative abundance of the species (Fig.3a) and the relative abundance of broken specimens (Fig.2d) have a close relation to water depth.

Gephyrocapsa oceanica Kamptner. This is an important species in coccolith assemblages in modern oceans and abundant in marginal seas around the western Pacific Ocean, it is a major component of coccolith assemblages in the East and South China Seas (Okada and Honjo, 1975; Chen and Shieh, 1982; Okada, 1983; Wang and Samtleben, 1983; Wang and Cheng, 1985). G. oceanica (Fig.3b) is also abundant and widespread in this area, and found in all samples counted for relative abundance. The relative abundance varies from $0.6 \%$ to $70 \%$. The high values $(>25 \%)$ are in the northern continental shelf at water depths of less than $150 \mathrm{~m}$ and in the lower continental slope at water depths of more than $2000 \mathrm{~m}$.

Florisphaera profunda Okada \& Honjo. F. profunda (Fig.3c), in terms of its dominance, is third only to $E$. huxleyi and $G$. oceanica. It is found in all assemblages counted. It is abundant $(>10 \%)$ in sediments from water depths of 1000 to $2000 \mathrm{~m}$. It has been widely neglected due to its unusual shape, so few references to the species can be found. According to Okada and Honjo (1973), living F. profunda is abundant in the deeper surface waters $(100-150 \mathrm{~m})$ over a wide temperature range (10$28^{\circ} \mathrm{C}$. Okada (1983) suggested that its relative abundance in surface sediments shows a positive correlation with water depth from the lower continental shelf to abyssal depths and that $F$. profunda dominates the associations in deep basins. This study found a different distribution. The relative abundance of $F$. profunda increases with water depth to $2000 \mathrm{~m}$ but decreases below this depth.

Calcidiscus leptoporus (Murray \& Blackman) Loeblich \& Tappan. C. leptoporus (Fig.3d) is distributed in water depth from 1000 to $3500 \mathrm{~m}$. Its average relative abundance is $0.79 \%$, with values greater than $0.8 \%$ mainly found in water depths from 2000 to $3500 \mathrm{~m}$. The different varieties of C. leptoporus proposed by McIntyre etal. $(1967,1970)$ were not distinguished because total numbers counted were low.

Umbilicosphaera sibogae (Weber-van Bosse) Gaarder. U. sibogae (Fig.3e) is not abundant (average relative abundance is $2.86 \%$ ), but it is present in most samples (frequency is $89.58 \%$ ). There is little regularity of relative abundance variation although most of the stations in which the value is over $4 \%$ come from water depths between 1000 and $3000 \mathrm{~m}$. McIntyre and Bé (1967) distinguished cold water and warm water forms of $U$. sibogae. They were not distinguished in this study because of their low relative abundance. The species was also found in the East China Sea (Wang and Cheng, 1985), but with lower relative abundances than those found here.

Syracosphaera pulchra Lohmann. This species is rare (average relative abundance is $0.84 \%$ ) and there is no obvious pattern to the relative abundance variation (Fig.3f).

Umbellosphaera tenuis (Kamptner) Paasche. Although $U$. tenuis is rare (average relative abundance is $0.43 \%$ ) (Fig.3g), it is present in most samples (frequency $87.50 \%$ ).

Helicosphaera carteri (Wallich) Kamptner. The relative abundance of $H$. carteri (Fig.3h) is very low (average is only $0.32 \%$ ), however, it is widely distributed in the area (frequency $93.75 \%)$.

\section{Assemblage Zones}

Based on the distribution of species and their relative abundance in the surface sediments, three assemblage zones (Fig.4a) can be established:

Zone 1. Zone 1 approximately corresponds to the northern continental shelf $(<150 \mathrm{~m})$. G. oceanica and E. huxleyi are abundant in the zone. F. profunda, Umbellosphaera irregularis, $U$. sibogae and Umbilicosphaera hulburtiana can be found.

Zone 2. Zone 2 is situated in the upper continental slope at depths of 150 to $2000 \mathrm{~m}$. E. huxleyi is predominant, G. oceanica and $F$. profunda are common in the zone. $U$. irregularis, $U$. sibogae, U. tenuis, Thoracosphaera heimii, Cricosphaera calvata and Discosphaera tubifer can be found. The zone can be subdivided into two subzones based on relative abundance variation of $F$. profunda. $F$. profunda is more abundant in subzone $2 \mathrm{~b}$ than in $2 \mathrm{a}$.

Zone 3. Zone 3 is in the lower continental slope ( $>2000 \mathrm{~m})$. G. oceanica is abundant, E. huxleyi is still common, but much less abundant than in zone 2. C. leptoporus, F. profunda, U. sibogae, $U$. irregularis, $U$. tenuis, $H$. carteri and $H$. hyalina can be found. 

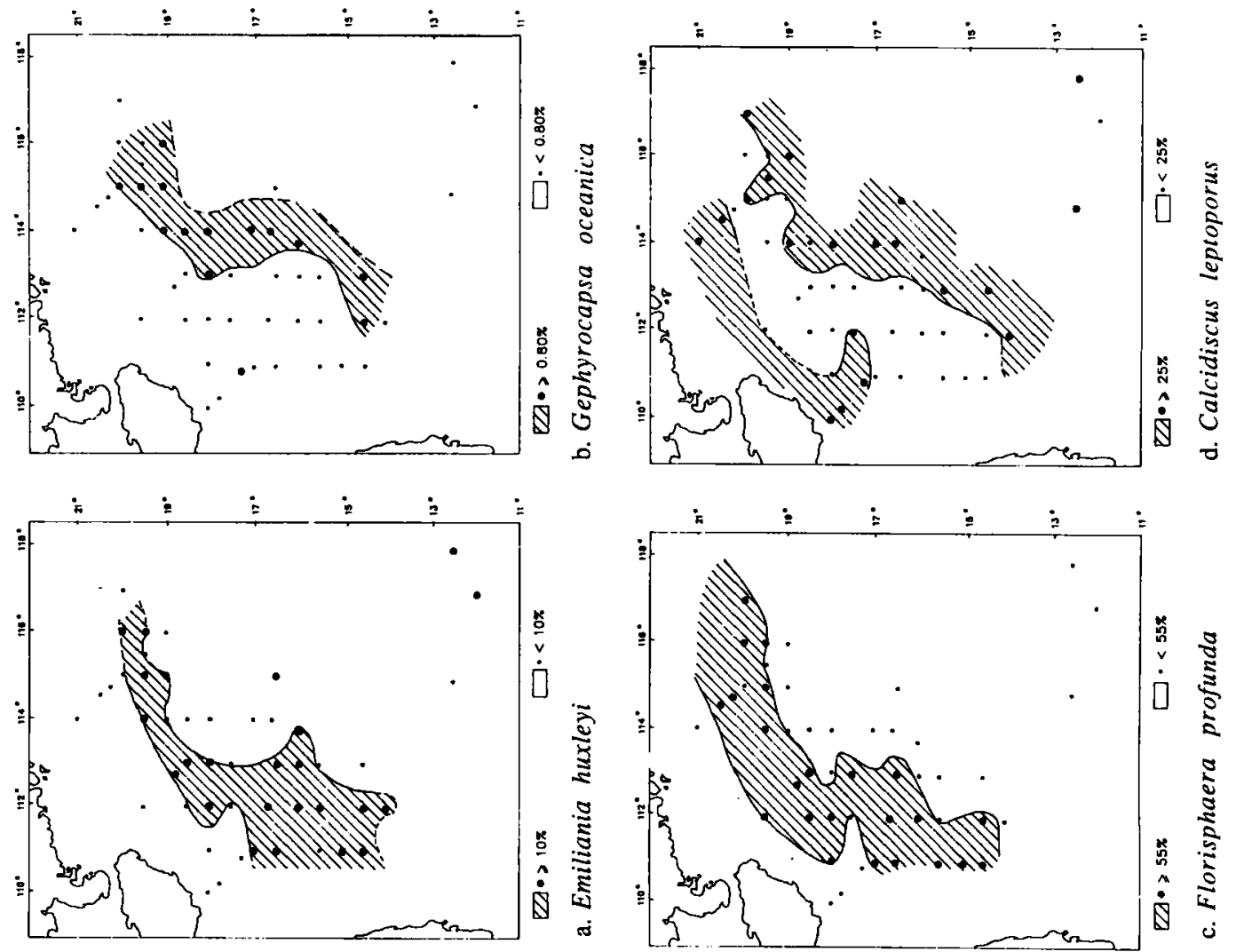

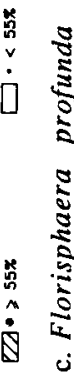
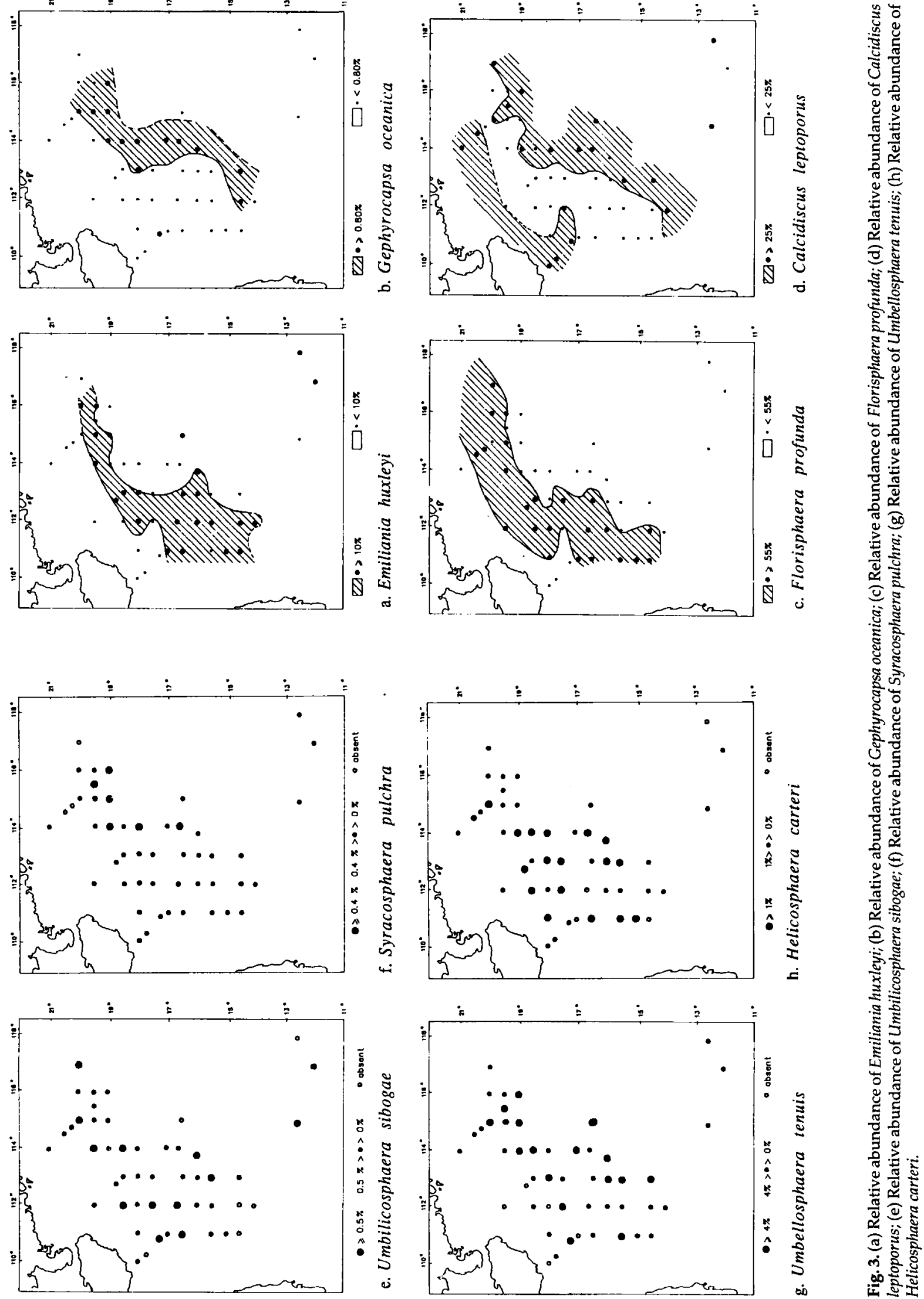


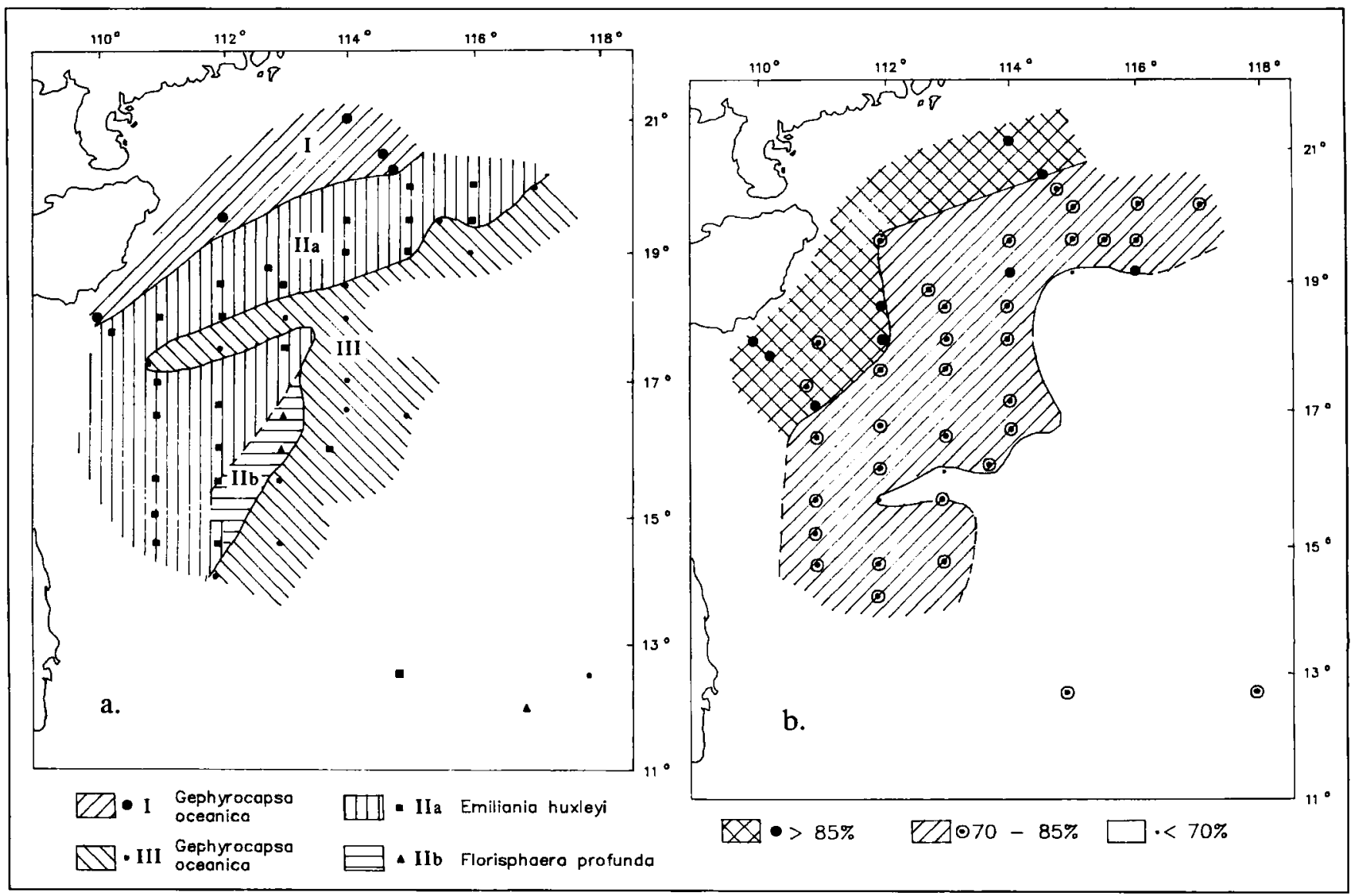

Fig. 4. (a) Calcareous nannofossil zones; (b) Distribution of small calcareous nannofossils (E. huxleyi G. oceanica)

\section{Specimen Size}

E. huxleyi and G. oceanica are smaller than 6 microns and can be designated "small nannofossils". The percentage of the small nannofossils is higher (over $85 \%$ ) nearshore and lower seawards (Fig.4b).

\section{DISCUSSION}

\section{Comparison}

The nannofossil assemblages in the central and northern parts of the South China Sea can be compared with those in the southern part of the Sea (Chen \& Shieh, 1982). The dominant species are the same, E. huxleyi and G. oceanica. There is a similar relative abundance variation trend of dominantspecies. G. oceanica prevails in nearshore environments, increasing in number towards the shoreline, while E. huxleyi increases in relative abundance towards continental slope and open ocean environments, decreasing again in the deep sea basin. But $E$. huxleyi predominates in the central and northern parts, and $G$. oceanica predominates in the southern part. What caused this difference remains to be studied.

Tab. 4 compares assemblages for the East China Sea (Wang and Cheng, 1985) and the study area. They are generally similar, however, the dominance of E. huxleyi and G. oceanica is higher in the East China Sea. The relative abundances of other species, especially warm water species, $U$. irregularis, $U$. sibogae and $O$. fragilis are higher in the South China Sea. These differences may result from the difference in latitudes. The South China Sea is situated in the tropics, the variation of surface water temperature there is less than that in the East China Sea.

Roth and Coulbourn (1982) recognized four coccolith assemblages (equatorial, central, transitional and subarctic) (Tab.4) in surface sediments of the North Pacific. They found that the coccolith assemblages followed the distribution of surface water masses. The central assemblage is dominated by E. huxleyi and G. oceanica. Although not a dominant species, $U$. tenuis was considered an important water-mass discriminator because it is restricted to the central water-mass. Comparing the average nannofossil assemblage in the central and northern South China Sea with the Pacific assemblages, that of the South China Sea is most closely equivalent to the central assemblage of the North Pacific, as shown by the dominance of E.huxleyi and G.oceanica, and the presence of $U$. tenuis(Tab.4).

\section{Controlling Factors}

E. huxleyi and G. oceanica are adapted to different environments. The former is the most ubiquitous species in today's seas, and can be found from tropical to subpolar waters; the latter is a warm water species, occurring in tropical, subtropi$\mathrm{cal}$ and temperate zones. The high water temperature in the 
South China Sea is responsible for the dominance of G. oceanica and E. huxleyi in the area. E. huxleyi is found in low to highly fertile waters throughout the world's oceans, but G. oceanica dominated in highly fertile and productive waters. Nutrients (e.g. phosphate) have an effect on G. oceanica. In the Gulf of Aqaba (Elat), Red Sea, Winter (1982) found that the distribution of $G$. oceanica was closely related to the distribution of phosphate. While G. oceanica in surface sediments was decreasing with phosphate from south to north, E. huxleyi was increasing. So it is likely that the riverine nutrient input cause the higher productivity of $G$. oceanica in the coastal area. However, the predominance of G. oceanica over E. huxleyi in the deep water area might be due to dissolution of delicate $E$. huxleyi. Evidence for this is provided by the increase in broken specimens of $E$. huxleyi in samples from below $2000 \mathrm{~m}$ (Fig.2d). Also the increase in C. leptoporus in deep water (Zone 3) are presumably dissolution effects.

The distribution of nannofossils in surface sediments is also influenced by sedimentological factors. Gartner (1981) found that on the continental shelf of the northern Gulf of Mexico coccoliths were relatively rare in the predominantly detrital sediments, even though they were produced in abundance in the water column. He thought this was due to the dilution by detrital materials. The continental shelf of the studied area receives a high input of terrigenous materials from the Zhujiang and Hanjiang Rivers, so it is likely that the low abundance of nannofossils nearshore is a result of dilution by terrigenous materials. As noted above, the distribution of calcareous nannofossils is closely related to the sediment carbonate content. A low value of abundance often corresponds to a low value of carbonate content. Although there is a close relationship between distributions of nannofossil and carbonate, carbonate content depends not only on nannofossils but also on other factors. Distribution of sediment carbonate in the South China Sea is mainly controlled by three factors: dilution by non-carbonate components, supply of calcareous skeletons of organisms, and carbonate dissolution. Carbonate content is lower near shore (e.g. $12.30 \%, 11.80 \%, 18.80 \%$ and $16.60 \%$ in stations G81, G82, G83 and G86) (Tab.5) due to dilution by terrigenous materials. It is also controlled by the supply of biogenic carbonate. Its distribution is closely related to these fossils, for example, foraminifers and nannofossils. It decreases towards abyssal plain as foraminifers (Zheng, 1987) and nannofossils (Figs.2b and 2c) do. Another important controlling factor of the distribution and content of carbonate is preservation. Carbonate dissolution increases with depth as bottom water becomes more undersaturated in calcium carbonate (Kennett, 1982). So low value of carbonate content including foraminifers and nannofossils $(<10 \%)$ could be attributed to the carbonate dissolution in deep sea. The relation between nannofossil abundance and sediment grain size reflects, to a certain extent, the effect of sorting on grain size, which results in more abundant nannofossils in fine sediments than in coarse ones.

\section{CONCLUSIONS}

1. Calcareous nannofossil abundance in surface sediments increases from continental shelf to slope, with a decrease from lower continental slope to abyssal basin.
2. E. huxleyi and G. oceanica are dominant species. The high relative abundance zones of the latter are situated in northern continental shelf and lower continental slope. Highest value of the former is in the area between water depths about 150 to 2000 metres.

3. The nannofossil assemblages in the northern and central parts of the South China Sea are similar to those in the East China Sea and in the central zone of the North Pacific Ocean.

4. There are two main groups of controlling factors: a) ecological factors including water temperature and supply of nutrients, b) sedimentological factors including dilution by terrigenous materials, deep water carbonate dissolution and the sorting effect.

\section{ACKNOWLEDGEMENTS}

I wish to express my deep gratitude to Prof. Wang Pinxian for his guidance on the study. I also wish to thank Dr. A. R. Wyatt for critically reading the manuscript, Dr. H. Okada for guidance in identification of some species and Mr. A. Thawley and Miss Wu Meiying for help with draughting figures. Second Institute of Oceanography, State Oceanic Administration of China and South China Sea Headquarters of Geological Survey, MGMR are gratefully acknowledged for providing some data on the bathymetry and contents of carbonate and sand. Thanks are due to Miss Xia Peifen, Shi Zuoyi and Mr. Liu Zhiwei of Tongji University for technical assistance with the SEM.

\section{Manuscript received October 1991 \\ Manuscript accepted July 1992}

\section{REFERENCES}

Chen, M.-P. and Shieh, K.-S. 1982. Recent nannofossil assemblages in sediments from Sunda Shelf to Abyssal Plain, South China Sea. Proc. Nat. Sci. Council (Taizuan, China), Part A, 6: 250-285.

Gartner, S., 1981. Calcareous nannofossils in marine sediments. The Oceanic Lithosphere, C. Emiliani (ed.), John Wiley and Sons, 7: 11451177.

Kennett, J.P., 1982. Marine Geology, 813pp., Prentice-Hall, Inc., Englewood Cliffs, N. J. 07632.

McIntyre, A. and Bé, A.W.H., 1967. Modern coccolithophoridae of the Atlantic Ocean. I Placoliths and Cyrtoliths. Deep-Sea Res., 14: 561597.

McIntyre, A., Bé, A.N.H. \& Preiksitas, R. 1967. Coccoliths and the Pliocene-Pleistocene boundary. Progr. Oceanogr., 4: 3-25.

McIntyre, A., Bé, A.N.H., \& Roche, M.B. 1970. Modern Pacific coccolithophorida: a Paleontological thermometer. Trans. N. Y. Acad. Sci., 32: 720- 731 .

Okada, H., 1983. Modern nannofossil assemblages in sediments of coastal and marginal seas along the western Pacific Ocean. Utrecht Micropaleont. Bull., 30: 171-187.

Okada, H. and Honjo, S. 1973. The distribution of oceanic coccolithophorids in the Pacific. Deep-Sea Res., 20: 355-374.

Okada, H. and S. Honjo, S. 1975. Distribution of Coccolithophores in Marginal Seas along the Western Pacific Ocean and in the Red Sea. Mar. Biol., 31: 271-285.

Pliysical Geography of China Compilation Committee, Chinese Academy of Sciences, 1979. Plysical Geography of China: Geographyof Neighboring Seas, 224pp., Science Press, Beijing (in Chinese).

Roth, P.H. and Coulbourn, W.T. 1982. Floral and solution patterns of coccoliths in surface sediments of the North Pacific. Mar. 
Micropaleont., 7: 1-52.

South China Sea Institute of Oceanology, Academia Sinica, 1981. Topographic map of the South China Sea $(1: 6,000,000)$. Guangzhou (in Chinese).

Varol, O., 1985. Distribution of calcareous nannoplankton in surface sediments from intertidal and shallow marine regimes of a marginal sea: Jason Bay, South China Sea. Mar. Micropaleont., 9: 369-374.

Wang Pinxian and Cheng Xinrong, 1985. Distribution of calcareous nannoplankton in the East China Sea. In: Wang Pinxian et al. (eds.), Marine Micropaleontology of China, 218-228, China Ocean Press and Springer-Verlag.

WangPinxian and Min Qiubao, 1981. A preliminary study of calcareous nannoplankton in bottom sediments of the East China Sea. Acta
Oceanologica Sinica, 3: 188-192 (in Chinese, with English abstract). Wang Pinxian and C. Samtleben, 1983. Calcareous nannoplankton in surface sediments of the East China Sea. Mar. Micropaleont., 8: 249259

Winter, A., 1982. Paleoenvironmental interpretation of Quaternary coccolith assemblages from the Gulf of Aqaba (Elat), Red Sea. Revta. Esp. Micropaleontol., 14: 291-314.

Zhang Jijun and W.G. Siesser, 1986. Calcareous nannoplankton in continental shelf sediments, East China Sea. Micropaleontology, 32: 271-281.

Zheng Lianfu, 1987. A preliminary study on the foraminifera in surface sediments of the central South China Sea. Donghai Marine Science, 5: 19-41 (in Chinese, with English abstract).

$\begin{array}{lrrr}\text { N } & \text { D(m) } & \text { a/ } 10 f & \text { A } \\ \text { Z4 } & 2 & 1 & 0.1 \\ \text { Z5 } & 5 & 0 & 0.0 \\ \text { Z6 } & 6 & 0 & 0.0 \\ \text { Z7 } & 6 & 1 & 0.1 \\ \text { Z14 } & 7 & 35 & 4.0 \\ \text { B22 } & 7 & 0 & 0.0 \\ \text { Z8 } & 8 & 2 & 0.2 \\ \text { B16 } & 12 & 100 & 11.4 \\ \text { B23 } & 13 & 23 & 2.6 \\ \text { B24 } & 13 & 1 & 0.1 \\ \text { Z21 } & 15 & 18 & 2.1 \\ \text { B7 } & 15 & 32 & 3.7 \\ \text { B3 } & 19 & 137 & 15.7 \\ \text { B8 } & 19 & 9 & 1.0 \\ \text { B10 } & 19 & 15 & 1.7 \\ \text { Z15 } & 20 & 31 & 3.5 \\ \text { Z22 } & 20 & 5 & 0.6 \\ \text { B1 } & 20 & 46 & 5.3 \\ \text { B19 } & 20 & 25 & 2.9 \\ \text { Z9 } & 21 & 31 & 3.5 \\ \text { B15 } & 22 & 15 & 1.7 \\ \text { B21 } & 22 & 37 & 4.2 \\ \text { B2 } & 25 & 81 & 9.3 \\ \text { Z10 } & 29 & 110 & 12.6 \\ \text { Z16 } & 29 & 83 & 9.5 \\ \text { B4 } & 29 & 160 & 18.3 \\ \text { Z1 } & 30 & 9 & 1.0 \\ \text { B14 } & 30 & 98 & 11.2 \\ \text { B9 } & 32 & 12 & 1.4 \\ \text { B18 } & 34 & 25 & 2.9 \\ \text { B5 } & 36 & 197 & 22.5 \\ \text { Z17 } & 41 & 55 & 6.3 \\ \text { B20 } & 41 & 22 & 2.5 \\ \text { Z11 } & 42 & 143 & 16.4 \\ \text { B6 } & 42 & 82 & 9.4 \\ \text { Z18 } & 47 & 31 & 3.5 \\ \text { B12 } & 49 & 25 & 2.9 \\ \text { Z2 } & 50 & 182 & 20.8 \\ \text { Z12 } & 53 & 352 & 40.3 \\ \text { B11 } & 55 & 45 & 5.1 \\ \text { B13 } & 55 & 31 & 3.5 \\ \text { B17 } & 62 & 167 & 19.1 \\ \text { Z13 } & 71 & 11 & 1.3 \\ \text { Z19 } & 72 & 275 & 31.5 \\ \text { Z3 } & 73 & 92 & 10.5 \\ \text { G86 } & 82 & 213 & 24.4 \\ \text { G87 } & 84 & 83 & 9.5 \\ \text { Z20 } & 95 & 510 & 58.3 \\ \text { G81 } & 95 & 66 & 7.6 \\ & & & \end{array}$

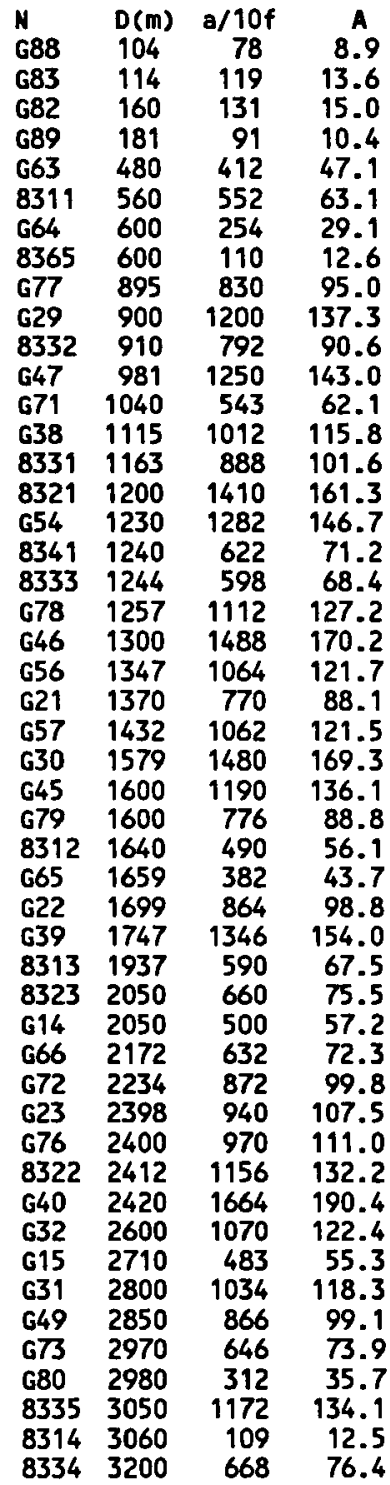

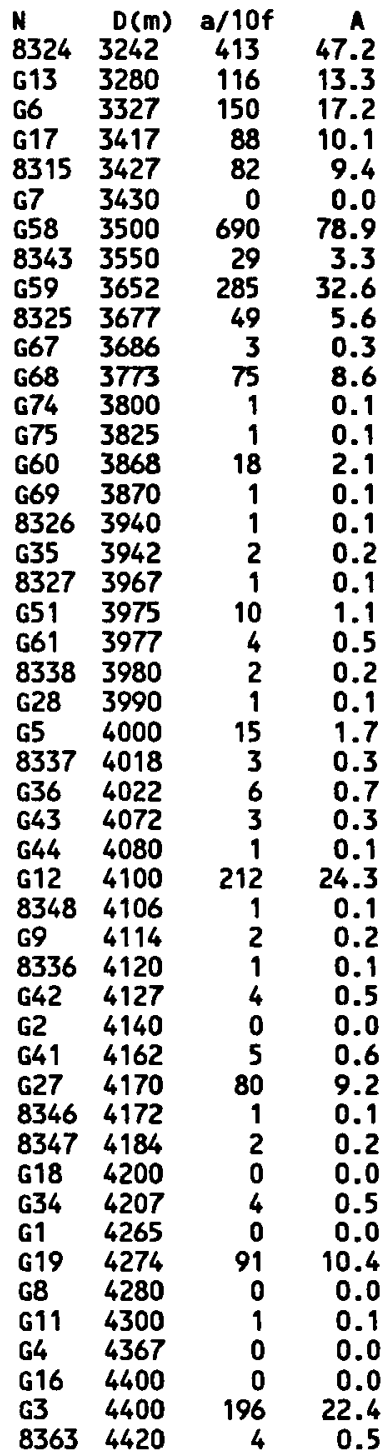

Table 1. Nannofossil abundance and water depth (bathymetric data provided by Second Institute of Oceanography, SOA and South China Sea Headquarters of Geological Survey, MGMR). N - Sample number 


\begin{tabular}{|c|c|c|c|c|c|c|}
\hline \multirow{2}{*}{$\begin{array}{l}\text { water } \\
\text { depth, } \\
\text { metres }\end{array}$} & \multirow{2}{*}{$\begin{array}{l}\text { number } \\
\text { of } \\
\text { samples }\end{array}$} & \multicolumn{5}{|c|}{ nannofossil } \\
\hline & & minimum & maximum & & average & \\
\hline \multirow{3}{*}{$<200$} & \multirow{3}{*}{53} & \multirow{3}{*}{0} & \multirow{3}{*}{510} & \multirow{3}{*}{78} & Beibu Gulf & 58 \\
\hline & & & & & $\begin{array}{r}\text { zhujiang } \\
\text { Estuary }\end{array}$ & 90 \\
\hline & & & & & $\begin{array}{c}\text { northern } \\
\text { shelf }\end{array}$ & 112 \\
\hline $\begin{array}{c}200-500 \\
500-1000 \\
1000-2000 \\
2000-3000 \\
3000-3500 \\
3500-4000\end{array}$ & $\begin{array}{r}1 \\
7 \\
20 \\
14 \\
10 \\
16\end{array}$ & $\begin{array}{r}412 \\
110 \\
382 \\
312 \\
0 \\
1\end{array}$ & $\begin{array}{r}412 \\
1250 \\
1488 \\
1664 \\
1172 \\
285\end{array}$ & \multicolumn{3}{|c|}{$\begin{array}{r}412 \\
713 \\
948 \\
843 \\
349 \\
30\end{array}$} \\
\hline$>4000$ & 25 & 0 & 212 & \multicolumn{3}{|c|}{25} \\
\hline
\end{tabular}

Table 2. Calcareous nannofossil abundancies with water depth

\begin{tabular}{|c|c|c|}
\hline Taxa & $\begin{array}{l}\text { average } \\
\text { abundance }\end{array}$ & $\underset{f}{\text { frequency }}$ \\
\hline $\begin{array}{l}\text { Anoplosolenia brasiliensis (Lohmann) Deflandre } \\
\text { Calcidiscus leptoporus (Murray \& Blackman) Loeblich \& Tappan } \\
\text { Calciopappus caudatus Gaarder \& Ramsfjell } \\
\text { Ceratolithus cristatus Kamptner } \\
\text { Ceratolithus spp. } \\
\text { Coccolithus pelagicus (Wallich) Schiller } \\
\text { Crenalithus sessilis (Lohmann) Okada \& MacIntyre } \\
\text { Crenalithus app. } \\
\text { Cricosphaera calvata Steinmetz } \\
\text { Discosphaera tubifer (Murray B Blackman) Ostenfeld } \\
\text { Emiliania huxleyi (Lohmann) Hay \& Mohler } \\
\text { Florisphaera profunda Okada Honjo } \\
\text { Gephyrocapsa ericsonii McIntyre \& Be } \\
\text { Gephyrocapsa oceanica Kamptner } \\
\text { Gephyrocapsa spp. } \\
\text { Hayaster perplexus (Bramlette \& Riedel) Bukry } \\
\text { Helicosphaera carteri (Wallich) Kamptner } \\
\text { Helicosphaera hyalina Gaarder } \\
\text { Neosphaera coccolithomorpha Lecal-schlauder } \\
\text { Oolithotus fragilis (Lohmann) Okada \& Mntyre } \\
\text { Pontosphaera japonica (Takayama) Nishida } \\
\text { Rhabdosphaera claviger Murray Blackman } \\
\text { Syracosphaera lamina Lecal-Schlauder } \\
\text { Syracosphaera pulchra Lohmann } \\
\text { Syracosphaera spp. } \\
\text { Umbellosphaera irregularis Paasche } \\
\text { Umbellosphaera tenuis (Kamptner) Paasche } \\
\text { Umbilicosphaera hulburtiana Gaarder } \\
\text { Umbilicosphaera sibogae (Weber-van Bosse) Gaarder } \\
\text { Thoracosphaera heimii (Lohmann) Kamptner } \\
\text { Thoracosphaera tuberosa Kamptner }\end{array}$ & $\begin{array}{r}0.56 \\
0.79 \\
0.03 \\
0.04 \\
0.04 \\
0.04 \\
0.05 \\
0.10 \\
0.12 \\
0.12 \\
54.82 \\
11.13 \\
0.67 \\
23.98 \\
0.02 \\
0.10 \\
0.32 \\
0.26 \\
0.21 \\
0.41 \\
0.01 \\
0.38 \\
0.14 \\
0.84 \\
0.76 \\
0.50 \\
0.43 \\
0.09 \\
2.86 \\
0.12 \\
0.01\end{array}$ & $\begin{array}{r}64.58 \\
89.58 \\
8.33 \\
10.42 \\
10.42 \\
8.33 \\
6.25 \\
16.67 \\
25.00 \\
29.17 \\
100.00 \\
100.00 \\
64.58 \\
100.00 \\
6.25 \\
27.08 \\
93.75 \\
29.17 \\
47.92 \\
77.08 \\
4.17 \\
64.58 \\
27.08 \\
91.67 \\
81.25 \\
64.58 \\
87.50 \\
20.83 \\
89.58 \\
33.33 \\
2.08\end{array}$ \\
\hline
\end{tabular}

Table 3. Average relative abundancies and frequencies of nannofossils.

\begin{tabular}{|c|c|c|c|c|c|c|c|}
\hline Species & \multicolumn{4}{|c|}{$\begin{array}{l}\text { North Pacific } \\
\text { Roth \& Coulbourn, } 1982\end{array}$} & \begin{tabular}{l}
\multicolumn{2}{c}{ East } \\
China Sea \\
Wang \& \\
Cheng, 1985
\end{tabular} & \multicolumn{2}{|c|}{$\begin{array}{l}\text { South } \\
\text { China Sea } \\
\text { This study }\end{array}$} \\
\hline $\begin{array}{l}\text { C. pelagicus } \\
\text { G. caribbeanica } \\
\text { C. leptoparus } \\
\text { F. profunda } \\
\text { E. huxleyi } \\
\text { U. sibogae } \\
\text { H. carteri } \\
\text { G. oceanica } \\
\text { O. fragilis } \\
\text { U. tenuis } \\
\text { U. irregularis }\end{array}$ & $\begin{array}{r}3.3 \\
6.8 \\
24.9 \\
12.9 \\
3.6 \\
38.9 \\
1.2 \\
2.2\end{array}$ & $\begin{array}{r}0.1 \\
2.7 \\
2.9 \\
42.6 \\
3.6 \\
3.0 \\
28.7 \\
0.6 \\
1.9 \\
1.5\end{array}$ & $\begin{array}{r}4.9 \\
42.8 \\
12.9 \\
30.0 \\
1.9 \\
1.0 \\
3.2\end{array}$ & $\begin{array}{r}57.8 \\
21.3 \\
6.0 \\
10.8\end{array}$ & $\begin{array}{r}57.1 \\
1.3 \\
0.2 \\
36.5 \\
0.1 \\
2.6\end{array}$ & $\begin{array}{r}0.9 \\
62.1 \\
3.2 \\
0.4 \\
26.6 \\
0.5 \\
0.5 \\
0.6\end{array}$ & $\begin{array}{r}0.8 * \\
11.1 * \\
54.8 * \\
2.9 * \\
0.3^{\star} \\
24.0 * \\
0.4 * \\
0.4 \star \\
0.5 *\end{array}$ \\
\hline
\end{tabular}

Table 4. Comparison of nannofossil assemblages in surface sediments of the South China Sea, the East China Sea (after Wang \& Cheng, 1985) with those of the North Pacific (after Roth \& Colbourn, 1982) (figures given in percent, "nannofossils counted with Florisphnera profinda) 


\begin{tabular}{|c|c|c|c|c|c|c|c|c|c|c|c|c|c|c|c|c|c|c|c|c|c|c|c|c|c|c|c|c|c|c|c|c|c|c|c|c|c|c|}
\hline Taxa & G3 & 66 & & G21 & 022 & & 029 & 630 & & 638 & & & $40 \mathrm{G}$ & & G46 & 649 & & & $7 \mathrm{G}$ & & & & & & G72 & 673 & & $G 7$ & $6 \pi$ & $8 \mathrm{G}$ & 790 & $81 \mathrm{E}$ & 82 & 83 & G86 & & $38 \mathrm{~GB}$ & \\
\hline A. brasiliensis & 1 & & & & $t$ & & 1 & & & $t$ & 1 & & 1 & & . & & & & 1 & $t$ & 1 & 1 & $t$ & $t$ & & & & 2 & & & 1 & 1 & t & 4 & $\mathrm{t}$ & & & \\
\hline c. leptopory & t & $t$ & $\mathrm{t}$ & 1 & 1 & 2 & 1 & $\mathrm{t}$ & 1 & $t$ & t & & $i$ & 3 & $t$ & 4 & & & 1 & 1 & t & $t$ & 2 & 1 & 1 & 2 & $t$ & $i$ & & & : & . & . & . & t & & & $1]$ \\
\hline c. caudatus & . & . & . & . & . & . & . & . & . & . & . & & - & . & . & & & & $\cdot$ & . & . & . & . & . & & & . & . & & & . & . & & & & & & \\
\hline c. cristatus & . & . & . & . & . & . & . & . & . & . & . & & . & . & . & . & & . & $\mathrm{t}$ & . & . & . & . & . & $\mathrm{t}$ & $t$ & . & . & & . & . & . & . & . & . & & . & \\
\hline Ceratolithus spo & . & $t$ & & & . & t & . & . & . & . & . & & . & . & . & $\mathrm{t}$ & & . & . & . & . & . & . & . & . & . & . & . & & . & . & . & . & . & . & & . & \\
\hline c. pelagicus & . & & & . & . & $\mathrm{t}$ & . & & . & . & . & & . & . & . & . & & & . & . & . & . & . & . & . & . & . & $\mathrm{t}$ & & . & . & . & . & . & . & & . & \\
\hline c. sessitis & & & . & . & . & . & . & $t$ & . & . & . & & . & & & & & & . & . & . & . & & . & . & & 1 & . & & & . & . & . & . & & & . & \\
\hline Crenalithus spo & . & 1 & . & . & . & . & . & . & . & . & . & & . & $t$ & . & . & & & $t$ & . & . & . & t & $t$ & . & . & . & . & & & t & . & . & . & & & & \\
\hline c. calvata & & . & & & . & . & . & t & t & $\mathrm{t}$ & . & & $t$ & . & . & 1 & & - & . & $t$ & . & i & . & $t$ & . & . & . & . & & . & . & . & . & . & . & & . & \\
\hline D. brouwer $i$ & & . & . & & . & . & . & . & . & . & . & & . & . & . & . & & . & . & . & . & . & . & . & . & 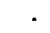 & . & 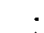 & & & $\mathrm{t}$ & & . & 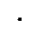 & & & & \\
\hline D. deflandrei & & . & . & & & . & & . & . & & & & & . & . & . & & & . & & . & & . & & . & & . & $\mathbf{t}$ & & & . & . & . & & . & & & \\
\hline D. tubifer & & & & & & & & & & $\mathrm{t}$ & & & $\mathrm{t}$ & & & & & & & $\mathrm{t}$ & & & & & & & & 1 & & & & $\mathrm{t}$ & $\mathrm{t}$ & $\mathrm{t}$ & & & & \\
\hline E. huxleyi (grill) & 4 & . & 2 & 2 & 6 & 4 & 13 & 7 & 2 & 4 & 2 & & 1 & 1 & 1 & 7 & & & 15 & 8 & 11 & 10 & 12 & 22 & 1 & 2 & 1 & 34 & & 4 & 2 & 7 & 2 & $t$ & 5 & & 4 & 18 \\
\hline E. huxleyi (solid) & 16 & 1 & 7 & 15 & 6 & 8 & 20 & 9 & 5 & 14 & 17 & & 22 & 14 & 18 & 2 & 2 & & 7 & 24 & 17 & 10 & 4 & 6 & 13 & 1 & 1 & 4 & 18 & & 17 & 19 & 28 & 10 & & & 21 & 14 \\
\hline E. huxleyi (open) & 11 & e & 4 & 5 & 3 & 1 & 7 & 4 & 2 & 10 & 2 & & 4 & 2 & 3 & & & & 6 & 3 & 6 & 9 & 5 & & 2 & & & & & & 3 & 5 & 3 & 2 & 1 & & 5 & 5 \\
\hline E. huxleyi (broken) & 19 & 15 & 36 & 55 & 48 & 32 & 30 & 34 & 32 & 51 & 30 & & 25 & 19 & 64 & 11 & 1 & & 33 & 27 & 44 & 42 & 33 & 16 & 33 & 13 & 18 & ; & 5 & & 34 & 17 & 16 & 65 & 23 & & 31 & 30 \\
\hline F. profunda & 5 & 24 & 15 & 14 & 14 & 9 & 7 & 30 & 7 & 11 & 24 & & 14 & 6 & 10 & 5 & & & 9 & 2 & 13 & 14 & 7 & 1 & 20 & 3 & 4 & 3 & 1 & 7 & 7 & 7 & 2 & 8 & t & & 3 & 9 \\
\hline G. aperta & & i & : & . & - & . & . & . & . & $\therefore$ & . & & & . & & . & & & . & . & & $\dot{0}$ & . & $\mathrm{t}$ & : & . & . & . & & & : & & & & & & & \\
\hline G. ericsonii & 2 & 1 & 1 & & $t$ & & & $t$ & & 1 & & & 1 & $\mathrm{t}$ & 1 & & & & & & 1 & $\mathrm{t}$ & & & $\mathrm{t}$ & & & & & & $\mathrm{t}$ & 2 & 1 & & & & & \\
\hline G. oceanica & 33 & 56 & 31 & $\dot{7}$ & 17 & 36 & $i i$ & 8 & 35 & 3 & 16 & & 17 & 44 & 1 & 58 & 4 & & 17 & 23 & 2 & 7 & 25 & 42 & 21 & 70 & 63 & 38 & & 2 & 28 & 39 & 41 & $i$ & 58 & & 26 & 12 \\
\hline G. protohuxleyi & & . & . & . & $\cdot$ & . & . & . & . & . & . & & . & . & . & & & & . & . & . & . & . & . & . & $t$ & . & . & & & . & . & . & $\mathrm{t}$ & . & & . & \\
\hline Gephyrocapsa spp & & . & . & - & - & - & - & - & . & - & . & & : & : & - & t & & & . & . & . & ; & . & : & : & . & : & : & & & - & . & : & - & - & & - & \\
\hline H. perplexus & $\mathrm{t}$ & . & . & - & - & . & - & - & . & - & i & & $\mathrm{t}$ & $\mathrm{t}$ & . & . & & & - & . & . & 1 & - & $\mathrm{t}$ & t & - & t & $\mathrm{t}$ & & & . & . & $t$ & - & : & & . & \\
\hline H. carter $\mathfrak{i}$ & $\mathrm{t}$ & i & $\mathrm{t}$ & t & $\mathrm{t}$ & $t$ & t & $\mathrm{t}$ & $\mathrm{t}$ & $\mathrm{t}$ & t & & t & $\mathrm{t}$ & i & $\mathrm{t}$ & & & $\mathrm{t}$ & $\mathrm{t}$ & $\mathrm{t}$ & $\mathrm{t}$ & $i$ & $t$ & t & $t$ & & $t$ & & & . & $\mathrm{t}$ & $\mathrm{t}$ & $\mathrm{t}$ & $\mathrm{t}$ & & . & \\
\hline H. hyalina & & $i$ & & & & $i$ & $\mathrm{t}$ & $t$ & $\mathrm{t}$ & $t$ & ts & & i & $\mathrm{t}$ & $\mathrm{t}$ & $\mathrm{t}$ & & & & . & $\mathrm{t}$ & $t$ & $i$ & $\mathrm{t}$ & i & $t$ & & $\mathrm{t}$ & & $t$ & $\dot{t}$ & . & . & $\mathrm{t}$ & . & & $\dot{t}$ & \\
\hline N. coccolithomorpha & 1 & . & $t$ & . & $t$ & $\mathrm{t}$ & & $\mathrm{t}$ & $\mathrm{t}$ & . & 8 & & $\mathrm{t}$ & $\mathrm{t}$ & . & $\mathrm{t}$ & & & t & . & . & $i$ & 1 & e & $\mathrm{t}$ & $t$ & $\mathrm{t}$ & $t$ & & & $t$ & . & . & . & & & & \\
\hline 0 . fragilis & 1 & : & 1 & $\mathbf{t}$ & . & 1 & 1 & . & $\mathrm{t}$ & . & t & & 1 & $\mathrm{t}$ & . & $\mathrm{t}$ & & $t$ & 1 & $\mathrm{t}$ & . & $\mathrm{t}$ & $\mathrm{t}$ & 1 & $\mathrm{t}$ & $\mathrm{t}$ & $\mathrm{t}$ & $\mathrm{t}$ & & . & $i$ & . & $\mathrm{t}$ & . & t & & : & \\
\hline P. japonica & $\mathrm{t}$ & . & . & . & . & . & . & . & . & . & . & & $\mathrm{t}$ & . & . & . & & & . & . & . & . & . & . & . & . & . & . & & . & . & . & . & . & . & & & \\
\hline P. lacunosa & & & & & & . & & & . & . & . & & . & . & . & $t$ & & & . & $t$ & & . & $t$ & . & . & $\mathrm{t}$ & & & & . & & . & . & . & & & & \\
\hline R. claviger & 1 & . & . & $\mathrm{t}$ & . & $\mathrm{t}$ & $\mathrm{t}$ & 1 & 2 & $\mathrm{t}$ & $t$ & & 1 & $t$ & . & $i$ & & & $\mathrm{t}$ & $t$ & $i$ & $\mathrm{t}$ & $\mathrm{t}$ & t & $\mathrm{t}$ & . & $i$ & 2 & & & $\mathrm{t}$ & . & $\mathrm{t}$ & & & & & \\
\hline s. abies & & : & : & . & : & . & . & . & 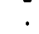 & : & & & . & • & . & & & & & $\cdot$ & & & . & . & & : & . & - & & - & & . & & & & & & \\
\hline 5. lamina & $\mathrm{t}$ & . & & . & & . & $t$ & & & & & & & & & & & & $\mathrm{t}$ & $\mathrm{t}$ & $\mathrm{t}$ & & & & & & & & & & & & 1 & 1 & & & & \\
\hline s. pulchra & 1 & & 1 & & $t$ & t & 1 & 1 & 2 & 1 & 1 & & 1 & $t$ & 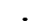 & 1 & & 2 & $i$ & 1 & $i$ & 1 & 2 & 1 & 1 & $t$ & $\mathrm{t}$ & 1 & & $\mathrm{t}$ & 1 & $i$ & $\mathrm{t}$ & $i$ & & & 1 & \\
\hline Syracosphaera spp & i & . & $\mathrm{t}$ & : & . & $i$ & 1 & . & 1 & . & 1 & & 1 & $\mathrm{t}$ & $i$ & $\mathrm{t}$ & & $t$ & 1 & 3 & 1 & $\mathrm{t}$ & $\mathrm{t}$ & $i$ & $\mathrm{t}$ & $\mathrm{t}$ & . & 1 & & & $i$ & $i$ & . & 3 & & & 2 & \\
\hline 1. heimii & & . & & & & & & & $\mathrm{t}$ & & se & & t & & . & $\mathrm{t}$ & & & $t$ & $\mathrm{t}$ & & . & . & $\mathrm{t}$ & t & . & . & $\mathrm{t}$ & & & $\mathrm{t}$ & . & . & . & t & & & \\
\hline T. tuberosa & & & . & & . & . & . & & & & & & & & 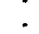 & & & & $\mathrm{t}$ & & & & & & 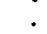 & $\cdot$ & & & & : & & : & & & & & : & \\
\hline u. irregular is & 1 & & & & & t & $t$ & 1 & 1 & $\mathrm{t}$ & 1 & & ; & 1 & 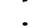 & $t$ & & & 2 & $i$ & $i$ & 1 & 1 & $t$ & 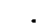 & $t$ & $\mathrm{t}$ & $\mathrm{t}$ & & & $t$ & . & 1 & . & $\mathrm{t}$ & & & \\
\hline u. tenuis & 2 & & & & & i & $t$ & i & 1 & $\mathrm{t}$ & te & & 1 & $i$ & i & $i$ & & 1 & t & $i$ & i & $i$ & 1 & $\mathrm{t}$ & t & $t$ & i & 1 & & $i$ & 1 & $i$ & . & $i$ & & & & \\
\hline U. hulburtiana & & & & & & & & & 1 & & & & t & & $\cdot$ & $\mathrm{t}$ & & & & & & & & $\mathrm{t}$ & & & & & & & & $\mathrm{t}$ & & & & & & \\
\hline U. sibogae & 1 & 1 & 1 & $\mathrm{t}$ & 3 & 4 & 4 & 3 & 7 & 2 & 4 & & 5 & 6 & . & 6 & & & 3 & 3 & . & 2 & 6 & 4 & 4 & 5 & 8 & 5 & & $\mathrm{t}$ & 2 & . & 2 & . & 1 & & 3 & 1 \\
\hline$x$ sar & i & 5 & 5 & 4 & 3 & 6 & $?$ & 8 & 4 & 10 & 17 & & 19 & 4 & 3 & & & & 12 & 24 & 2 & 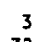 & 3 & 5 & 4 & 2 & 2 & 5 & & 3 & 19 & 78 & 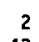 & 71 & 53 & & & 77 \\
\hline & & & & 28 & 28 & 38 & 33 & 40 & 38 & 49 & 48 & & 58 & 26 & 28 & 36 & & & 45 & & 32 & & 31 & 34 & 32 & 23 & 25 & 27 & & 26 & 36 & 12 & 12 & 19 & 17 & & 22 & 49 \\
\hline
\end{tabular}

\begin{tabular}{|c|c|c|c|c|c|c|c|c|c|c|c|c|c|c|}
\hline \multirow{2}{*}{\begin{tabular}{|l} 
Taxa \\
A. brasiliensis
\end{tabular}} & \multicolumn{4}{|c|}{8311831283138321} & \multicolumn{10}{|c|}{$\begin{array}{lll}8322 & 8323 \quad 8324 & 83318332 \quad 8333 \quad 83348335 \quad 83418365\end{array}$} \\
\hline & 3 & & $t$ & $\mathrm{t}$ & $\mathrm{t}$ & $t$ & & 1 & 1 & 1 & & & 1 & \\
\hline c. leptoporus & $\mathrm{t}$ & 2 & . & $\mathrm{t}$ & t & 3 & 2 & 1 & $\mathrm{t}$ & $\mathrm{t}$ & 1 & $\mathrm{t}$ & $\mathrm{t}$ & $\mathrm{t}$ \\
\hline c. caudatus & & . & $\mathrm{t}$ & & . & . & & $\mathrm{t}$ & - & - & $\therefore$ & - & . & $\mathbf{t}$ \\
\hline c. cristatus & $\mathrm{t}$ & . & . & 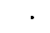 & . & . & . & . & . & . & $\mathrm{t}$ & : & . & : \\
\hline Ceratolithus spp & . & . & . & · & . & . & . & 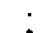 & & - & & $\mathrm{t}$ & . & $\mathrm{t}$ \\
\hline c. pelagicus & . & · & · & - & - & - & - & $\mathrm{t}$ & - & - & 1 & . & - & \\
\hline C. sessilis & - & : & & & & 1 & . & $\dot{.}$ & - & - & 1 & - & $\cdot$ & \\
\hline $\begin{array}{l}\text { Crenalithus spp } \\
\text { c. calvata }\end{array}$ & : & $\dot{.}$ & . & . & & $\mathrm{t}$ & : & $i$ & $\dot{.}$ & i & . & $\dot{.}$ & : & $i$ \\
\hline o. brouweri & . & . & . & . & . & - & . & . & . & - & . & . & . & \\
\hline D. deflandrei & - & & - & & - & : & $\therefore$ & - & - & : & - & - & : & \\
\hline D. tubifer & . & & - & 1 & & $\mathrm{t}$ & $t$ & . & $\therefore$ & $\mathrm{t}$ & & : & $\mathrm{t}$ & 1 \\
\hline E. huxleyi (grill) & 4 & 3 & 2 & 2 & 2 & 6 & 7 & 11 & 10 & 1 & 3 & 1 & 6 & 12 \\
\hline E. huxleyi (solid) & 17 & 7 & 23 & 45 & 19 & 4 & 7 & 17 & 21 & 31 & $\mathrm{t}$ & 2 & 19 & 5 \\
\hline E. huxleyi (open) & 3 & 4 & 10 & 6 & 4 & 6 & & 6 & 6 & 1 & & & 6 & 3 \\
\hline E. huxleyi (broke) & 48 & 52 & 46 & 21 & 58 & 38 & 37 & 32 & 37 & 33 & 13 & 15 & 40 & 17 \\
\hline F. profunda & 14 & 14 & 12 & 9 & 12 & 12 & 9 & 14 & 11 & 23 & 7 & 30 & 13 & 28 \\
\hline G. aperta & & & & 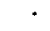 & & & & & & & & & & \\
\hline G. ericsuni i & 1 & 1 & 3 & : & 1 & & 1 & t & 1 & $t$ & $\therefore$ & $t$ & & 1 \\
\hline G. oceanica & 4 & 12 & 9 & 7 & 1 & 21 & 28 & 8 & 8 & 5 & 62 & 41 & 7 & 22 \\
\hline G. protohuxleyi & - & - & - & : & - & . & - & - & . & - & - & . & - & - \\
\hline Gephyrocapsa spp & & - & - & t & - & - & - & - & & : & - & - & - & \\
\hline $\begin{array}{l}\text { H. perplexus } \\
\text { H. carteri }\end{array}$ & $t$ & $i$ & i & i & $i$ & i & $i$ & $i$ & $t_{t}^{t}$ & $t$ & $i$ & $i$ & $i$ & $i$ \\
\hline $\begin{array}{l}\text { H. carteri } \\
\text { H. hyal ina }\end{array}$ & $\mathrm{t}$ & $\mathrm{t}$ & $\mathrm{t}$ & . & $\mathrm{t}$ & $\mathrm{t}$ & $\mathrm{t}$ & $\mathrm{t}$ & . & . & $\mathrm{t}$ & $\mathrm{t}$ & . & $\mathrm{t}$ \\
\hline N. coccol i thomorpha & $\mathrm{t}$ & . & . & & . & $\mathrm{t}$ & : & $\mathrm{t}$ & : & : & 1 & & & \\
\hline 0. fragilis & $\mathrm{t}$ & $t$ & - & 1 & $\mathrm{t}$ & 1 & t & ' & t & $t$ & t & 1 & $\mathrm{t}$ & 1 \\
\hline P. japonica & - & $\cdot$ & - & - & - & - & - & - & - & - & - & - & - & - \\
\hline P. Lacunosa & & - & t & & - & - & - & & $\cdot$ & ; & & ; & ; & · \\
\hline R. claviger & $\mathrm{t}$ & - & $\mathrm{t}$ & 1 & . & - & $t$ & 1 & - & $\mathrm{t}$ & 1 & $\mathrm{t}$ & t & - \\
\hline 5. abies & & - & - & 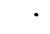 & 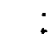 & & t & " & & . & $\cdot$ & - & & \\
\hline s. Lamina & 1 & & - & . & $\mathrm{t}$ & & $\mathrm{t}$ & & $\mathrm{t}$ & & & & & 1 \\
\hline s. pulchra & $t$ & 1 & $\mathrm{t}$ & 2 & $\mathrm{t}$ & 1 & 2 & 1 & & 1 & 2 & 1 & 1 & 1 \\
\hline Syracosphaera Spp & 1 & t & 1 & 1 & $\mathrm{t}$ & t & t & 1 & 1 & $t$ & - & - & 1 & 1 \\
\hline Y. heimii & 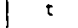 & - & & & & . & - & $\mathrm{t}$ & 1 & $\mathrm{t}$ & - & - & . & $\mathrm{t}$ \\
\hline T. tuberosa & & & & & & & & & & & 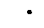 & & & \\
\hline U. irregularis & $t$ & . & - & 1 & 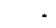 & 1 & . & 2 & 1 & $\mathrm{t}$ & . & . & 1 & 2 \\
\hline U. tenuis & 1 & $\mathrm{t}$ & $\mathrm{t}$ & $\mathrm{t}$ & t & $t$ & t & 1 & 1 & $\mathrm{t}$ & $\mathrm{t}$ & $t$ & $\mathrm{t}$ & $t$ \\
\hline $\begin{array}{l}\text { U. hulburtian } \\
\text { U. sibogae }\end{array}$ & 1 & 3 & $i$ & 3 & . & $\begin{array}{l}t \\
6\end{array}$ & $t^{t}$ & 2 & 1 & ; & 6 & $\begin{array}{l}t \\
7\end{array}$ & 3 & 1 \\
\hline U. sibogae & 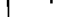 & 2 & & & & 8 & 2 & 2 & 1 & 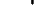 & 4 & 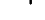 & $J$ & \\
\hline$\%$ sond & 27 & 4 & 5 & 1 & 2 & 3 & 6 & 4 & 12 & 39 & 2 & 3 & 4 & 61 \\
\hline $\mathbf{x} \mathrm{CaCO}_{3}$ & 45 & 29 & 30 & 22 & 28 & 35 & 19 & 33 & 54 & 67 & 31 & 37 & 30 & 92 \\
\hline
\end{tabular}

Table 5. Relative abundancies of nannofossils and percentages of sand and $\mathrm{CaCO}_{3}$. (Data on sand and $\mathrm{CaCO}_{3}$ provided by Second Institute of Oceanography, SOA, China) 